\title{
Is magnetic resonance imaging reliable for the evaluation of the ruptured or healed anterior cruciate ligament?
}

\author{
Manyetik rezonans görüntüleme yırtık veya iyileşmiş ön çapraz bağın \\ değerlendirilmesi için güvenilir midir? \\ O. Şahap Atik, MD, A. Turgay Çavuşoğlu, MD, Tacettin Ayanoğlu, MD. \\ Department of Orthopedics and Traumatology, Medical Faculty of Gazi University, Ankara, Turkey
}

\begin{abstract}
Magnetic resonance imaging (MRI) is the preferred imaging technique to evaluate the intact, ruptured or healed anterior cruciate ligament (ACL). However, its effectiveness in the diagnosis of chronic tears with synovialization has not been searched. During conservative treatment of torn ACL, there is a reparative process with proliferation of synovial scar tissue which may produce a bridge. This healing, so called synovialization, may cause ACL to be misdiagnosed as intact on MRI. This is true for old ruptures of ACL. Magnetic resonance imaging is reliable in the evaluation of acute ACL ruptures. However, MRI is not reliable to evaluate the stability of the healed ACL after conservative treatment, and the ruptures due to degenerated ACLs.
\end{abstract}

Keywords: Healed anterior cruciate ligament; magnetic resonance imaging; ruptured anterior cruciate ligament.

Anterior cruciate ligament (ACL) injuries are common and the economic impact of these injuries is high. ${ }^{[1,2]}$ However, we still do not know the optimal management of a torn ACL of the knee. ${ }^{[3]}$

There are studies reporting poor capacity for primary healing after the rupture of ACL. ${ }^{[4,5]}$ Woo et al. ${ }^{[5]}$ demonstrated that midsubstance ACL injuries have limited healing ability.

However, there are also some reports showing spontaneous healing after the rupture of ACL.[6,7] Two patients who were reported in one of these papers had a distal or a proximal tear; thus, these conditions for healing may be favorable. ${ }^{[6]}$

\section{$\ddot{O} Z$}

Manyetik rezonans görüntüleme (MRG) sağlam, kopmuş veya iyileşmiş ön çapraz bağ (ÖÇB) değerlendirilmesinde tercih edilen yöntemdir. Ancak sinovyalizasyon ile birlikte olan kronik yırtıkların tanısındaki etkinliği araştırılmamıştır. Yırtık ÖÇB'nin konservatif tedavisi sırasında, bir köprü oluşturabilen sinovyal skar dokusu proliferasyonu ile birlikte onarım süreci vardır. Sinovyalizasyon denilen bu iyileşme MRG'de ÖÇB'ye sağlammış gibi yanlış tanı konulmasına neden olabilir. Bu, eski ÖÇB yırtıkları için doğrudur. Manyetik rezonans görüntüleme akut ÖÇB yırtıklarının değerlendirilmesinde güvenilirdir. Ancak, MRG konservatif tedaviden sonra iyileşmiş ÖÇB ve dejenere olmuş ÖÇB'lere bağlı yırtıkların stabilitesinin değerlendirilmesinde güvenilir değildir.

Anahtar sözcükler: İyileşmiş ön çapraz bağ; manyetik rezonans görüntüleme; yırtık ön çapraz bağ.

Magnetic resonance imaging (MRI) is the preferred imaging technique to evaluate the intact, ruptured or healed ACL. However, its effectiveness in the diagnosis of chronic tears with synovialization has not been specifically analyzed. ${ }^{[8]}$

We had some conservatively treated patients with ruptured ACLs due to trauma whose ACLs looked healed on the MRI are associated with variable degrees of insufficiency in physical examination, and some of them required reconstruction surgery (Figures 1 and 2).

We also had some patients with unicompartmental osteoarthritis of the knee for

\footnotetext{
- Received: January 28, 2015 Accepted: February 09, 2015
}

- Correspondence: O. Şahap Atik, MD. Gazi Üniversitesi Tıp Fakültesi Ortopedi ve Travmatoloji Anabilim Dalı, 06500 Beşevler, Ankara, Turkey. Tel: +90 312 - 2025528 Fax: +90 312 - 2129008 e-mail: satikmd@gmail.com 

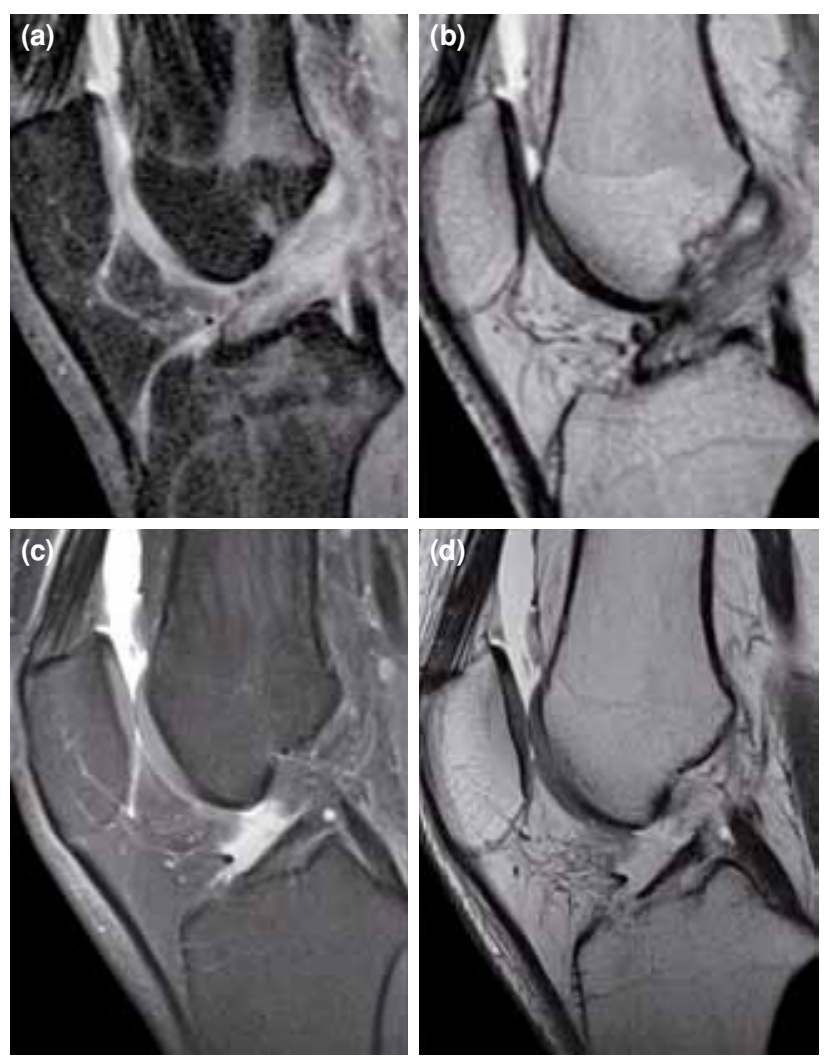

Figure 1. (a, b) Magnetic resonance imagings showing complete rupture of anterior cruciate ligament due to trauma in $T_{1}$ and $T_{2}$-weighted sagittal image. (c, d) Magnetic resonance imagings showing complete healing of anterior cruciate ligament in $T_{1}$ and $T_{2}$-weighted sagittal image 4.5 years later.

whom unicompartmental knee replacement was planned. Magnetic resonance imaging of those patients revealed intact ACLs (Figure 3). However, physical examination showed some degrees of instability in those patients. Radiograms with valgus stress revealed instability similar to the instability obtained with pivot shift test (Figure 4). During surgery, their ACLs were almost totally ruptured due to degeneration and they required total knee replacement.

\section{Why do we misdiagnose status of anterior cruciate ligament in the evaluation with magnetic resonance imaging?}

During conservative treatment of torn ACL, there is a reparative process with proliferation of synovial granulation scar tissue which may produce a bridge. This healing, so called synovialization, may cause ACL to be misdiagnosed as intact on MRI. This is true for old ruptures of ACL. Synovialization can be diagnosed with arthroscopy; however, this is an invasive procedure.
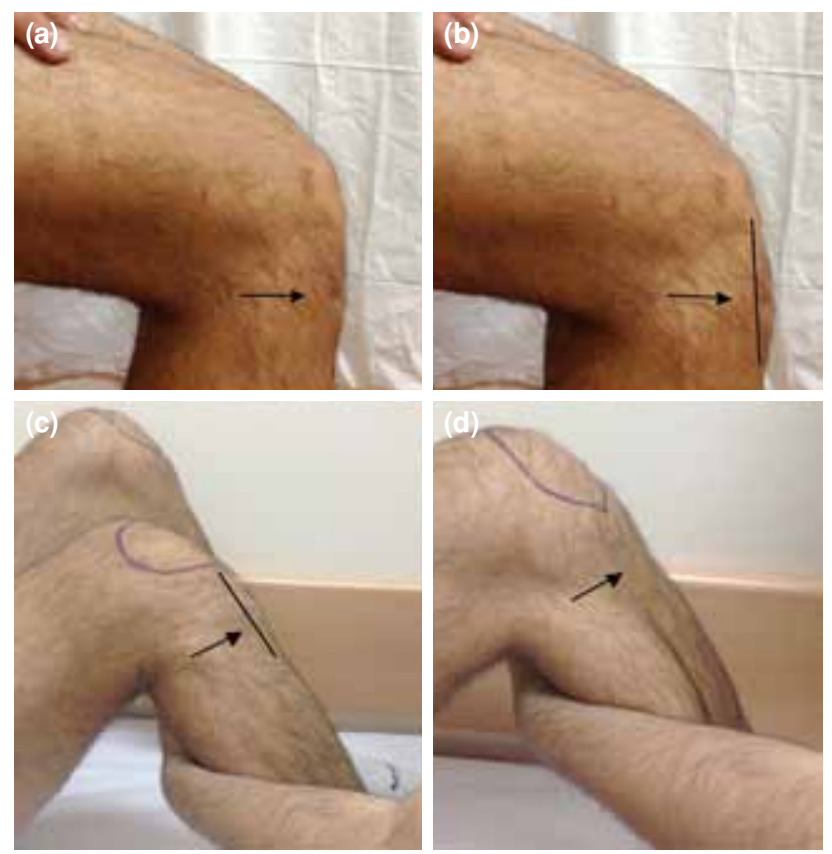

Figure 2. $(\mathbf{a}, \mathbf{b})$ Voluntary anterior translation of the right leg. (c) Positive anterior drawer test of right knee. (d) Negative anterior drawer test of left knee.

It is well known that an injury to a ligament results in a situation that the ligament function is restored by the formation of scar tissue that is biologically and biomechanically inferior to the tissue it replaces. Arnoczky et al. ${ }^{[9]}$ reported that the mechanical and ultrastructural properties are not completely normal even one year after dissection of the ligament regardless of the treatment modality.

\section{Conclusion}

Magnetic resonance imaging is reliable in the evaluation of acute ACL ruptures. However, MRI
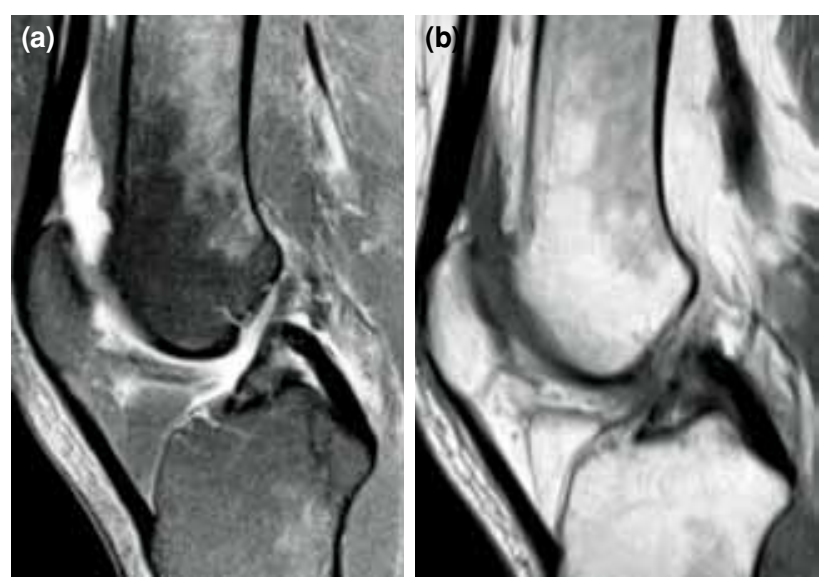

Figure 3. (a, b) Magnetic resonance imagings showing almost intact anterior cruciate ligament but some signal changes due to degeneration in $\mathrm{T}_{1}$ and $\mathrm{T}_{2}$-weighted sagittal image. 

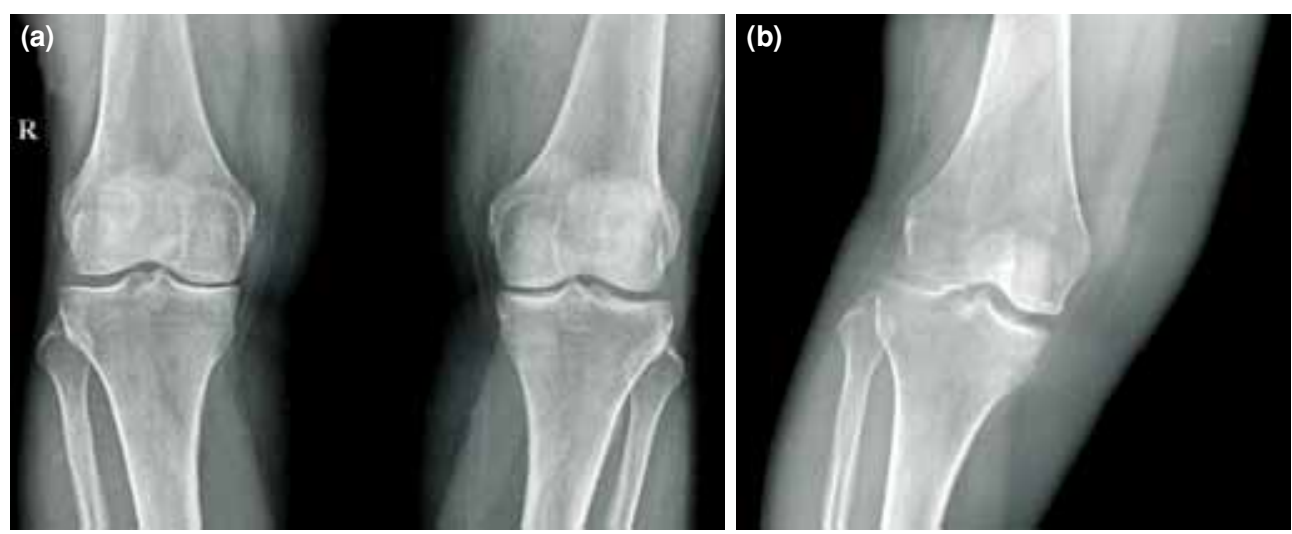

Figure 4. (a) Radiogram showing unicomparmental (medial) osteoarthritis of right knee; (b) Radiogram taken with valgus stress showing instability similar to instability obtained with pivot shift test of same knee.

is not reliable to evaluate the stability of the healed ACL after conservative treatment, and the ruptures due to degenerated ACLs.

\section{What can we do to avoid misdiagnosis in the evaluation of anterior cruciate ligament?}

First of all, we have to pay attention to the complaints of the patients. These may lead us for a better evaluation.

We also recommend that the degree of instability should be evaluated by physical examination, including anterior drawer test, Lachman test and pivot shift test. The relationship between the MRI and physical examination findings may be also helpful for a better diagnosis of ACL rupture.

\section{Declaration of conflicting interests}

The authors declared no conflicts of interest with respect to the authorship and/or publication of this article.

\section{Funding}

The authors received no financial support for the research and/or authorship of this article.

\section{REFERENCES}

1. Öztürk S, Kılıç D. What is the economic burden of sports injuries? Eklem Hastalik Cerrahisi 2013;24:108-11.

2. Mather RC 3rd, Koenig L, Kocher MS, Dall TM, Gallo P, Scott DJ, et al. Societal and economic impact of anterior cruciate ligament tears. J Bone Joint Surg [Am] 2013;95:1751-9.

3. Atik OŞ. Do we know the optimal management of a torn anterior cruciate ligament of the knee? Eklem Hastalik Cerrahisi 2014;25:63.

4. Hefti FL, Kress A, Fasel J, Morscher EW. Healing of the transected anterior cruciate ligament in the rabbit. J Bone Joint Surg [Am] 1991;73:373-83.

5. Woo SL, Chan SS, Yamaji T. Biomechanics of knee ligament healing, repair and reconstruction. J Biomech 1997;30:431-9.

6. Kurosaka M, Yoshiya S, Mizuno T, Mizuno K. Spontaneous healing of a tear of the anterior cruciate ligament. A report of two cases. J Bone Joint Surg [Am] 1998;80:1200-3.

7. Fujimoto E, Sumen Y, Ochi M, Ikuta Y. Spontaneous healing of acute anterior cruciate ligament (ACL) injuries - conservative treatment using an extension block soft brace without anterior stabilization. Arch Orthop Trauma Surg 2002;122:212-6.

8. Higueras Guerrero V, Torregrosa Andrés A, Martí-Bonmatí L, Casillas C, Sanfeliu M. Synovialisation of the torn anterior cruciate ligament of the knee: comparison between magnetic resonance and arthroscopy. Eur Radiol 1999;9:1796-9.

9. Arnoczky SP, Rubin RM, Marshall JL. Microvasculature of the cruciate ligaments and its response to injury. An experimental study in dogs. J Bone Joint Surg [Am] 1979;61:1221-9. 